\title{
FIRST SURVEY OF THE FUNGI FROM THE BAKWENA CAVE IN SOUTH AFRICA SUGGESTS LOW HUMAN DISTURBANCE
}

\author{
Adriaana Jacobs ${ }^{1}$, Duduzile Msimang², and Eduard Venter ${ }^{3, C}$
}

\begin{abstract}
Currently there are no studies on the microbial karst niche in South Africa. Most of the studies on these environments focus on archaeology and animals that occur in caves. However, there are several caves that are threatened by urban development of the surrounding areas. The Bakwena Cave is such a threatened cave with extensive urban development of the surrounding grassland biome it is located in. The cave is located in dolomite and the entrance is a sinkhole. This cave serves as a permanent roost for a large population of Natal clinging bats Miniopterus natalensis. The ecosystem of the cave is driven by the deposition of guano by the bats, as there is no deep penetration of plant debris from the outside. To identify the fungal component of the microbial ecosystem, we sampled guano, soil, and sediment from various areas within the cave over a period of one year. All isolations were performed on low-nutrient medium to restrict the colony growth and to ensure that all culturable fungi were obtained. These isolates were barcoded using the ITS1 gene region to identify them and to establish a baseline of fungi occurring in South African caves. The majority of isolates associated were Aspergillus and Penicillium species identified in previous studies from cave environments. Some opportunistic pathogens were identified that could have an impact as more people visit the cave due to its close proximity to housing developments. However, currently the cave fits a model that indicates it has a low level of human disturbance. Our study is the first on the cave fungal component in South Africa and provides a baseline that can advise developers and environmental impact assessments on fungal species found in caves.
\end{abstract}

\section{Introduction}

The Bakwena Cave is located to the south of Pretoria in Gauteng, South Africa, in an escarpment of dolomite (Martini and Kavalieris, 1976). It is a publically accessible cave that is located on the perimeter of the Agricultural Research Council Irene campus (S25 $53^{\prime} 53.3^{\prime \prime}$ E28 $\left.8^{\circ} 13^{\prime} 19.8^{\prime \prime}\right)$. The cave serves as a permanent roost for Natal clinging bats (Miniopterus natalensis) (Durand et al., 2012), while Temminck's hairy bat (Myotus tricolor) and Geoffry's horseshoe bat (Rhinolophus clivosus) occur intermittently. The cave is irregularly used by amateur speleologists and other groups. Entrance to the cave is by rappelling through a cone-shaped sinkhole to the top of a shaft that has a $5 \mathrm{~m}$ ladder fitted to the side. The bottom of the ladder rests on the top of a scree slope that provides access to the large main cavern below (Fig. 1), with several large guano deposits found in the main chamber. The cave system consists of a large main chamber that has three tunnels leading from it. The tunnel located in the most eastern part of the cave extends at a slope for 22 meters to end at the edge of the water table. This cave is one of the few dolomitic caves in South Africa that provide access to the water table (Durand et al., 2012). At the southwestern end of the cave, two tunnels lead to two smaller chambers. The largest of these is a permanent roost of the Natal clinging bat and contains large amounts of guano. The second chamber is accessible through a narrow tunnel. There are no bats roosting in this chamber, and it has a very narrow tunnel that leads from it. The average temperature and relative humidity in the main chamber are $15.4 \pm 0.4^{\circ} \mathrm{C}$ and $93.2 \pm 2.7 \%$ and for the larger side chamber are $21.1 \pm 1.6^{\circ} \mathrm{C}$ and $100.0 \pm 0.6 \%$. The Bakwena Cave was surrounded by large tracts of grassland that serve as foraging area for the bats. Currently the cave is under threat by urban development, and the resulting habitat shrinkage and fragmentation will likely have a negative impact on the bats that utilize the cave as a roost. As more housing is developed close to the cave, there will most probably be more visitors that could increase the levels of fungal-associated diseases.

Karst environments such as those found in the Bakwena Cave host different microbial groups, and the diversity is affected by the energy status of the cave (Groth et al., 1999; Jurado et al., 2008). These microbes occupy a variety of substrates, such as sediments, vermiculations, guano, and decaying organic material that create different ecological niches (Nováková, 2009; Portillo et al., 2008). The cave is surrounded by grass and trees that grow down the entrance slope that was created when the sinkhole formed and results in soil and plant debris being carried into the cave during the rainy and windy seasons. The depth to which this debris penetrates is limited by the percolating effect of the scree slope. The large number of bats, ranging between an estimated 800 and 1850 depending on the season (Durand et al., 2012), roosting in the cave results in large guano deposits that provides a rich niche for the growth of microbes. Global research suggests that the most common cave fungi are Ascomycetes, with Zygomycetes and Basidiomycetes

\footnotetext{
${ }_{1}^{1}$ Biosystematics Division, Plant Health and Protection Research, Agriculture Research Council, Queenswood, Pretoria, South Africa

${ }^{2}$ Department of Botany and Plant Biotechnology, University of Johannesburg, Auckland Park, Johannesburg, Gauteng, South Africa

${ }^{3}$ Department of Botany and Plant Biotechnology, University of Johannesburg, Auckland Park, Johannesburg, Gauteng, South Africa

c Corresponding Author: eduardv@uj.ac.za
} 
being isolated at less abundant levels (Vanderwolf et al., 2013). Most species isolated from caves are soil saprophytes, and the predominant differences reported between studies are introduced by spatial diversity patterns and substrate specificity (Vanderwolf et al., 2013). Karst environments have been considered extreme habitats inhabited by specialized species (Lorch et al., 2013). However, this assumption does not hold true for the mycological component of cave ecosystems, as very few species are considered truly troglobitic (Vanderwolf et al., 2013).

Recent trends in biology are the development of species barcodes and the use of these in ecological studies (Lahaye et al., 2008; Hollingsworth et al., 2009). In mycological phylogenetic analysis, the focus fell on the nuclear ribosomal DNA (nrDNA), as it is composed of highly conserved and variable domains (Woese et al., 1990; Barton et al., 2004). During the last decade large amounts of data were generated for the majority of known fungal species on this region. Therefore, this area was investigated and found to be the most suitable barcoding region for the fungi (Schoch et al., 2012) with the exception of a few genera (O'Donnell and Cigelnik, 1997). The nrDNA encodes for the ribosomal RNA that makes up part of the ribosome (Patwardhan et al., 2014) and is considered as a useful marker for phylogenetic studies (White et al., 1990; Begerow et al., 2010; Eberhardt, 2010). The nrDNA encodes multiple-copy loci and is commonly used, as all organisms except most viruses have ribosomes. An additional feature of the nrDNA region is that it incorporates both coding and non-coding DNA, which have various levels of selection on them due to their conserved and non-conserved nature. These nrDNA are organized in clusters of tandem repeats that consist of the internal transcribed spacer 1 (ITS1), 5.8S rRNA gene and ITS2. Due to the ITS2 region's functionality in RNA processing, it can be used to discriminate at species and subspecies level and contains unique secondary structures that can be used for alignment of higher taxonomic ranks like genus and order (Song et al., 2012). Thus, this region is the best to use as the DNA barcode marker for identifying both single taxa and mixed environmental isolates (Bellemain et al., 2010, Schoch et al., 2012).

Studies into the microbial niches contained in karst systems are few when compared to large ecological studies from plants and animals. There is also no fungal barcoding project to our knowledge that focuses specifically on karst ecosystems in Africa. The low cost associated with fungal barcoding of a biome or ecosystem provides an interesting opportunity to establish the different distribution patterns of fungi found in karst systems. The possibilities to discover new fungal species increases tremendously when coupled with next-generation sequencing. In this study, we aimed to establish a baseline for fungal species distribution found in a dolomitic cave. We sampled the culturable fungal population of the Bakwena Cave ecosystem over a twelve-month period (2009-2010) to establish a baseline for fungi found associated with this type of karst system.

\section{Materials and Methods}

Samples of dry and wet guano were collected aseptically into sterile containers between April 2009 and March 2010 from four sites in the Bakwena cave system (Fig 1). Sites one and two were in the main chamber and three and four in two different side chambers. All the samples were taken from areas that had no indication of human activity such as footprints or other disturbances. Sample 1 was taken from the main guano heap located in front of the shelf that led to the pair of side chambers. A soil sample was also occasionally taken from close to the guano heap. Sample 2 was taken from a guano heap that was used for measuring the accumulation of guano over time by another research group, although no evidence of any disturbance was recorded at each of our visits. This heap was located behind the earthen mound at the bottom of the scree slope that led from the entrance of the cave. Sample 3 was collected from the sediment at the edge of the water table that was reached through the eastern passage. Sample 4 was sampled from the side chamber where the largest roost of bats occurred and that was deemed the most pristine, with the least evidence of human activity because the entrance to the side chamber is difficult to manage. All samples were immediately placed on ice and transported to the laboratory, where samples were stored at $15{ }^{\circ} \mathrm{C}$ until processing. The physiological and physiochemical characteristics of the cave sediments, including moisture content, $\mathrm{pH}$, and organic matter of sediments were determined and reported by Durand et al. (2012).

To isolate the culturable fungal fraction from the cave ecosystem, isolations were made from all the collected guano and soil samples. The isolations were done by spreading $5 \mathrm{~g}$ of organic material onto potato carrot agar (nutrient poor media) (Crous et al., 2009) plates, amended with $0.02 \mathrm{~g} / \mathrm{L}$ tetracycline and $0.01 \mathrm{~g} / \mathrm{L}$ ampicillin to suppress bacterial growth, and then isolating all morphologically unique colonies after seven days of incubation at $20^{\circ} \mathrm{C}$. Following sub-culturing on malt extract agar media (Merck) to obtain pure cultures, all isolates were grouped into morphological taxonomic units (MTU) based on colony morphology, i.e. colony color and growth pattern. Single conidium (spore) cultures were obtained for all the isolates to ensure that a single genetic entity was used for further studies. All the singleconidial cultures were deposited in the PPRI collection of the National Collection of Fungi, Plant Protection Research, Agricultural Research Council, Pretoria, South Africa.

DNA was extracted from one representative of each MTU that was grown on potato dextrose agar (Merck) at $25^{\circ} \mathrm{C}$ for seven days, and mycelium was harvested by scraping it from the agar surface with a sterile spatula. The DNA was 


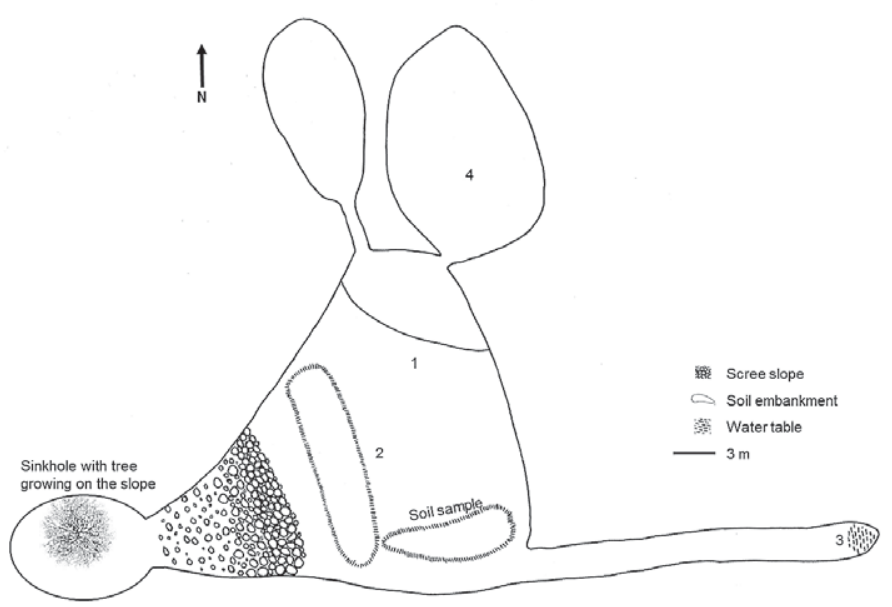

Figure 1. Layout of the Bakwena Cave. The entrance to the cave is located at the top of the scree slope; it is entered by rappelling down a cone-shaped sinkhole and climbing down a ladder that was installed at the top of the scree slope. A side view of the cave layout is available in Durand et al. (2012). Samples were taken from moist and dry guano at the indicated sampling sites. The bat colony was divided into two groups that were located above sampling sites 1 and 2 and in the side chamber where sample 4 was taken. Sample 3 was taken from sediment at the edge of the water table.

isolated using a DNeasy Plant Mini Kit (Qiagen) following the manufacturer's instructions. The extracted DNA was used as template in PCR reactions to amplify the ITS region of the rDNA gene region using the primer set ITS1 (5'CGAATCTTTGAACGCACATTG-3') and ITS4 (5'-CCGTGTTTCAAGACGGG-3') (White et al., 1990). Amplification of the ITS region from the fungal DNA was performed in $20 \mu \mathrm{l}$ PCR reaction mix containing $50 \mathrm{ng}$ DNA template, $0.5 \mu \mathrm{M}$ of each primer, $0.04 \mathrm{U}$ ExSel Taq polymerase (JMR Holdings), $0.25 \mathrm{mM}$ each dNTP, and $1 \mathrm{X}$ ExSel buffer. Amplification was performed on a MyCycler (Biorad) with initial denaturation for 3 minutes at $94^{\circ} \mathrm{C}$, followed by 30 cycles of 1 minute at $94^{\circ} \mathrm{C}, 1$ minute at $50{ }^{\circ} \mathrm{C}$ and 1 minute at $72^{\circ} \mathrm{C}$, with a 7 minute final extension at $72^{\circ} \mathrm{C}$. The amplicons were separated on a $1.5 \%(\mathrm{w} / \mathrm{v})$ agarose gel submerged in 1 X TAE $(40 \mathrm{mM}$ Tris-acetate $\mathrm{pH}$ 8.0, $1 \mathrm{mM}$ ethylenediamine tetraacetic acid) buffer for verification and viewed under UV-light. The PCR amplicons were purified using a QIAquick PCR Purification kit.

The MTUs identities were determined by sequencing the ITS amplicons on a 3130xI DNA Analyzer (Thermo Fisher Scientific) using the ABI PRISM ${ }^{\mathrm{TM}}$ Dye Terminator Cycle Sequencing Ready Reaction Kit (Thermo Fischer Scientific) with the same primers as those used in the PCR reactions. All of the sequences generated in this study were deposited in GenBank. The ITS1 barcode sequences generated from the MTUs were queried against the NCBI nucleotide sequence and MycoBank databases using BLASTn (basic local alignment search tool, Zhang et al., 2000) to ascertain their closest relationships using a similarity percentage that exceeded $95 \%$.

\section{Results}

Our study focused on isolating and characterizing only the culturable fungal species from the Bakwena Cave. Samples were obtained over a period of twelve months during which the temperature and relative humidity were also recorded (Durand et al., 2012). Isolated fungi were separated into 54 morphological taxonomic units (MTU) based on their colony morphology. From these a total of 93 isolates were deposited in the PPRI living culture collection of the National Collection of Fungi over the twelve-month sampling period. These are represented by the accessions numbers PPRI 22065-22077, 22114-22146, 22148-22150, 22635-22638, 22651-22652, 22654-22660, 22663-22665, 22670-22672, 22674-22681, 22683, 22686-22689, 22690-22705.

The ITS barcode amplicons generated for the individual isolates were about $600 \mathrm{bp}$ in size. The BLASTn results of the DNA barcodes generated for 38 MTUs distinguished six genera and 19 species (Table 1) from both databases. The species-level identifications were congruent for $81.5 \%$ of the isolates across the two databases. The majority of the strains belong to genera within the fungal order Eurotiales and the family Trichocomaceae. Genera found in the Trichocomaceae are morphologically characterized by well-developed mycelium that is often brightly colored. The significant genera in the Trichocomaceae include, among others, Penicillium and Aspergillus (Cannon and Kirk, 2007), with several genera known for their production of toxins that include aflatoxins, ochratoxins and patulins. Five genera that are frequently isolated from karst environments were also represented by our sampling. These were Penicillium, Aspergillus, Mucor, Candida, and Epicoccum (Vanderwolf et al., 2013). The genus Bionectria has been isolated from caves in the USA (Shapiro and Pringle, 2010). Six species that are regularly isolated from karst environments were Aspergillus versicolor (Nováková, 2009), P. chrysogenum (Nováková, 2009; Vanderwolf et al., 2013), P. brevicompactum (Vanderwolf et al., 2013), P. atramentosum (Nováková, 2009), P. pinophilum (Nováková, 2009), and M. circinelloides (Nováková, 2009). We also isolated two medically significant species, $A$. versicolor and $A$. ochraceus (Bayman et al., 2002; Engelhart et al., 2002). These species have been associated with fungal infections in immune-compromised individuals. Candida palmioleophila, a yeast, has been previously reported from bat guano sampled in Japan (Sugita et al., 2005). 
Table 1. Diversity of fungal isolates identified from the Bakwena cave. Identifications are based on barcode similarities to the MycoBank and NCBI databases. The MTU and NCBI accession numbers indicate the respective PPR culture number of the deposited fungal isolate and the nucleotide sequence deposited at the NCBI. The sampling site is indicated and cross references to sites indicated in Figure 1.

\begin{tabular}{|c|c|c|c|c|c|c|c|}
\hline MTU & $\begin{array}{c}\text { PPRI } \\
\text { Number }\end{array}$ & $\begin{array}{c}\text { MycoBank } \\
\text { Identification }\end{array}$ & $\begin{array}{c}\text { Similarity } \\
(\%)\end{array}$ & $\begin{array}{c}\text { NCBI } \\
\text { Identification }\end{array}$ & $\begin{array}{c}\text { Similarity } \\
(\%)\end{array}$ & NCBI Accession & Sampling Site \\
\hline 71 & 13380 & A. westerdijkiae & 100 & A. ochraceus & 100 & KY465907 & Main chamber - Moist guano \\
\hline 103 & 22141 & P. griseofulvum & 97.8 & P. griseofulvum & 100 & KY069890 & Water and sediment \\
\hline 96 & 22142 & P. brevicompactum & 100 & Penicillium sp. & 100 & KY069868 & Water and sediment \\
\hline 82 & 22143 & P. griseofulvum & 100 & P. griseofulvum & 100 & KY069885 & Water and sediment \\
\hline 77 & 22145 & Aspergillus sp. & 99.6 & A. ochraceus & 100 & KY069892 & Main chamber - Moist guano \\
\hline 76 & 22146 & A. westerdijkiae & 99.8 & A. westerdijkiae & 99 & KY069864 & Main chamber - Moist guano \\
\hline 78 & 22635 & Mucor flavus & 95.7 & M. flavus & 99 & KY069874 & Main chamber - Dry guano \\
\hline 97 & 22636 & P. chrysogenum & 96.8 & P. chrysogenum & 94 & KY069876 & Main chamber - Moist guano \\
\hline 44 & 22651 & P. chrysogenum & 100 & P. chrysogenum & 99 & KY069888 & Main chamber - Moist guano \\
\hline 67 & 22655 & A. westerdijkiae & 99.8 & A. westerdijkiae & 100 & KY069893 & Main chamber-Dry guano \\
\hline 54 & 22656 & P. crustosum & 100 & P. crustosum & 100 & KY465908 & Main chamber - Dry guano \\
\hline 46 & 22657 & P. commune & 96 & P. commune & 100 & KY069882 & Main chamber - Soil sample \\
\hline 28 & 22658 & P. crustosum & 98.4 & Penicillium sp. & 100 & KY069881 & Main chamber - Dry guano \\
\hline 59 & 22659 & P. griseofulvum & 100 & P. griseofulvum & 100 & KY069863 & Main chamber - Dry guano \\
\hline 49 & 22664 & P. crustosum & 100 & P. crustosum & 100 & KY069880 & Side chamber - Dry guano \\
\hline 51 & 22665 & A. westerdijkiae & 99.4 & A. westerdijkiae & 100 & KY069883 & Main chamber - Moist guano \\
\hline 36 & 22671 & C. palmioleophila & 99.2 & C. palmioleophila & 98 & KY069869 & Main chamber - Moist guano \\
\hline 33 & 22674 & A. ochraceus & 98.9 & A. ochraceus & 100 & KY069887 & Main chamber- Moist guano \\
\hline 39 & 22675 & A. westerdijkiae & 100 & A. westerdijkiae & 100 & KY465909 & Main chamber - Moist guano \\
\hline 93 & 22676 & P. chrysogenum & 99.8 & P. chrysogenum & 100 & KY069884 & Water and sediment \\
\hline 87 & 22678 & P. atramentosum & 100 & P. atramentosum & 100 & KY069875 & Main chamber - Dry guano \\
\hline 37 & 22681 & P. polonicum & 98.4 & P. polonicum & 100 & KY069866 & Side chamber - Moist guano \\
\hline 8 & 22682 & Meyerozyma caribbica & 97.5 & Me. caribbica & 100 & KY465906 & Main chamber - Dry guano \\
\hline 3 & 22683 & A. westerdijkiae & 100 & A. westerdijkiae & 98 & KY069872 & Main chamber - Moist guano \\
\hline 86 & 22689 & E. nigrum & 100 & E. nigrum & 100 & KY069867 & Main chamber - Moist guano \\
\hline 6 & 22691 & A. versicolor & 99.8 & A. versicolor & 99 & KY069865 & Main chamber - Moist guano \\
\hline 24 & 22696 & Bionectria ochroleuca & 99.4 & B. ochroleuca & 99 & KY069895 & Side chamber - Moist guano \\
\hline 26 & 22697 & A. versicolor & 99.6 & A. versicolor & 100 & KY069871 & Side chamber - Dry guano \\
\hline 42 & 22698 & A. westerdijkiae & 99.3 & A. westerdijkiae & 100 & KY069878 & Main chamber - Moist guano \\
\hline 50 & 22699 & P. brevistipitatum & 100 & P. griseofulvum & 100 & KY069894 & Main chamber - Dry guano \\
\hline 63 & 22701 & P. griseofulvum & 100 & P. griseofulvum & 100 & KY069877 & Side chamber - Dry guano \\
\hline 70 & 22702 & P. pinophilum & 99.6 & P. pinophilum & 100 & KY069886 & Main chamber-Dry guano \\
\hline 27 & 22703 & A. versicolor & 100 & A. versicolor & 100 & KY069870 & Side chamber - Dry guano \\
\hline 30 & 22705 & A. westerdijkiae & 100 & A. westerdijkiae & 100 & KY069873 & Side chamber - Dry guano \\
\hline 20 & 22935 & A. cretensis & 97.1 & A. ochraceus & 100 & KY069896 & Main chamber - Dry guano \\
\hline 48 & 22936 & P. crustosum & 100 & P. commune & 100 & KY069879 & Side chamber - Dry guano \\
\hline 79 & 22937 & M. circinelloides & 92.1 & M. circinelloides & 100 & KY069891 & Main chamber - Dry guano \\
\hline
\end{tabular}

\section{Discussion}

The study of karst systems in South Africa has been limited to macro fauna and flora and their anthropological value. The area surrounding Pretoria has numerous caves that incorporate archaeological sites and are studied extensively. One of these areas, The Cradle of Humankind, was proclaimed as a world heritage site in 1999 and is protected against development. The Bakwena Cave does not fall into such a proclaimed site and is very exposed to and impacted by urban development. To ascertain what the effect of new developments will have on caves such as the Bakwena Cave, the South African Karst Ecology Study Group (SAKES) was established in 2009 (Durand et al., 2012). SAKES set itself the aim to focus on macro and microbiota found in the Bakwena Cave and has focused on the bats, spiders, mites, amphi- 
pods, and microorganisms. Microorganisms in most natural systems have been considered ecologically important due to their involvement in carbon cycling as decomposers (Nielsen et al., 2011). In karst ecosystems, they perform a variety of other roles, including constituting the major food sources of non-predacious troglobitic invertebrates. Furthermore, the fungal component acts as parasites of cave insects (Vanderwolf et al., 2013).

The level of fungal species richness within a karst system is affected by the level of disturbance that the system undergoes (Shapiro and Pringle, 2010). Karst systems with medium disturbance levels and medium- to low-impact sites have significantly greater species numbers than more disturbed or very low disturbance sites. Based on the selection criteria proposed by Shapiro and Pringle (2010), the Bakwena Cave can be classified as a low-disturbance cave as only 19 culturable fungal species were obtained. This hypothesis is supported by the fact that there were no additional visits except by our sampling trips recorded to the cave. What was interesting is that only Penicillium species were associated with the soil, sediment, and water samples. Of these, only $P$. commune and $P$. brevicompactum were not isolated from any other medium in the cave, which could indicate that they were introduced by other means, most probably through human activity, or they are natural cave-dwelling species. Most of the identified fungi are saprophytes that either utilize dead plant material as food source or, in the case of the Bakwena Cave, bat guano.

Bats can affect the diversity of fungi found in caves through the transportation of spores, deposition of guano, and their carcasses. The guano that bats deposit in cave systems generally hosts the largest fungal diversity of all cave substrates studied (Vanderwolf et al., 2013). In our study, we expected the largest diversity of fungi to be isolated from the guano, compared with soil and sediment. We isolated the majority of species from the main chamber occurring either on moist or dry guano. The difference between the age and state of the guano did not add significantly to the fungal diversity. Several mite families were also identified from the cave, including the Acaridae (Sancassania sp.), the Laelapidae (Laelaps sp.) and the Uropodoidea (Durand et al., 2012). Two of these are known to feed on fungi (Krantz and Walter, 2009) and may be a contributing factor to the lower number of fungal isolates obtained.

The different genera and species isolated in this study corresponds well to previous karst studies (Nováková, 2009; Vanderwolf et al., 2013; Sugita et al., 2005; Shapiro and Pringle, 2010). Here, we isolated and identified 38 MTUs up to species level. For the majority of these, both databases reported the same species, but for some, only one database returned a species hit. For others, the two databases produced two different identities, due to the limited use of the ITS region for fungal species identification (Cannon and Kirk, 2007; O'Donnell and Cigelnik, 1997). This gene region works well for most fungal species, but in some instances, the region that is amplified does not contain enough phylogenetic signal to effectively separate or identify between closely related species.

A number of factors can influence the culturable fungal fraction obtained from a karst ecosystem (Vanderwolf et al., 2013). These include the isolation methods used, the species of bats occupying the cave, and the level of human disturbance (Shapiro and Pringle, 2010). According to Vanderwolf et al. (2013), the isolation methods used, including growth media and temperature, may also play a role. During this study, we used a nutrient-poor media (PCA) and incubated at $20^{\circ} \mathrm{C}$ that should have been sufficient for a large number of genera to be isolated. Shapiro and Pringle (2010) concluded that only fungal cultures obtained at an incubation temperature of $10^{\circ} \mathrm{C}$ are true cave dwellers, as the rest may present fungal species that utilize the organic material that came from outside the cave. In our study, we sampled mainly from guano, so the association with this substrate is fairly strong. Domsch et al. (2007) states that Eurotiales, especially Penicilium, is well adapted for cold temperatures, which may serve as a possible explanation for the dominance in our study. A study on dust collected from homes across the world revealed that the diversity of fungi found outside influences the diversity of fungi found inside (Visagie et al., 2014). This phenomenon might also hold true for fungi found in caves, where an area that is more diverse in its microbial populations will have a more diverse fungal population. The best way to further establish the fungal diversity would be to make use of metapopulation analysis to provide a much more complete picture of the niche.

\section{Conclusion}

Ours is the first study of the culturable fungal population of the Bakwena Cave and represents the first study of a fungal cave ecosystem in South Africa. We have identified several fungi that have previously been associated with caves, and this verifies the results that we have obtained. The correlation between our study and other published studies most probably indicates that the cave ecosystem is as healthy as others that have been studied. Our data for the fungal diversity indicate that the Bakwena Cave has experienced only low levels of disturbance until now. It further sets a baseline that can be used to advise on future developments surrounding the cave.

\section{References}

Barton, H.A., Taylor, M.R., and Pace, N.R., 2004, Molecular phylogenetic analysis of a bacterial community in an oligotrophic cave environment: Geomicrobiology Journal, v. 21, no. 1, p. 11-20. https://doi.org/10.1080/01490450490253428.

Bayman, P., Baker, J.L., Doster, M.A., Michailides, T.J., and Mahoney, N.E., 2002, Ochratoxin production by the Aspergillus ochraceus group and Aspergillus alliaceus: Applied and Environmental Microbiology, v. 68, no. 5, p. 2326-2329. https://doi.org/10.1128/AEM.68.5.2326-2329.2002. 
Begerow, D., Nilsson, H., Unterseher, M., and Maier, W., 2010, Current state and perspectives of fungal DNA barcoding and rapid identification procedures: Applied Microbiology and Biotechnology, v. 87, no. 1, p. 99-108. https://doi.org/10.1007/s00253-010-2585-4.

Bellemain, E., Carlsen, T., Brochmann, C., Coissac, E., Taberlet, P., and Kauserud, H., 2010, ITS as an environmental DNA barcode for fungi: an in silico approach reveals potential PCR biases: BMC Microbiology, v. 10, paper 189, 9 p. https://doi.org/10.1186/1471-2180-10-189.

Cannon, P.F., and Kirk, P.M. eds., 2007, Fungal Families of the World: Boston, CABI, 456 p.

Crous, P.W., Verkley, G.J.M., Groenewald, J.Z., and Samson, R.A. eds., 2009, Fungal Biodiversity: Utrecht, CBS-KNAW Fungal Biodiversity Centre, CBS Laboratory Manual Series 1, 269 p.

Domsch, K.H., Gams, W., and Anderson, T.H., 2007, Compendium of Soil Fungi, second ed.: Eching, IHW-Verlag, 672 p.

Durand, F., Swart, A., Marais, W., Jansen van Rensburg, C., Habig, J., Dippenaar-Schoeman, A., Ueckermann, E., Jacobs, A., de Wet, L., Tiedt, L., and Venter, E., 2012, Die karst-ekologie van die Bakwenagrot (Gauteng): Suid-Afrikaanse Tydskrif vir Natuurwetenskap en Tegnologie, v. 31 no. 1 , p. 1-17. https://doi.org/10.4102/ satnt. v31i1.275.

Eberhardt, U., 2010, A constructive step towards selecting a DNA barcode for fungi: New Phytology, v. 187, no. 2, p. 265-268. https://doi. org/10.1111/j.1469-8137.2010.03329.x.

Engelhart, S., Loock, A., Skutlarek, D., Sagunski, H., Lommel, A., Färber, H., and Exner, M., 2002, Occurrence of toxigenic Aspergillus versicolor isolates and sterigmatocystin in carpet dust from damp indoor environments: Applied and Environmental Microbiology, v. 68, no. 8, p. 3886-3890. https://doi.org/10.1128/AEM.68.8.3886-3890.2002.

Groth, I., Vettermann, R., Schuetze, B., Schumann, P., and Saiz-Jimenez, C., 1999, Actinomycetes in karstic caves of Northern Spain (Altamira and Tito Bustillo): Journal of Microbiological Methods, v. 36, no. 1-2, p. 115-122. https://doi.org/10.1016/s0167-7012(99)00016-0.

Hollingsworth, P.M., Forrest, L.L., Spouge, J.L., Hajibabaei, M., Ratnasingham, S., van der Bank, M., Chase, M.W., Cowan, R.S., Erickson, D.L., Fazekas, A.J., Graham, S.W., James, K.E., Kim, Ki-Joong, Kress, W.J., Schneider, H., van AlphenStahl, J., Barrett, S.C.H., van den Berg, C., Bogarin, D., Burgess, K.S., Cameron, K.M., Carine, M., Chacón, J., Clark, A., Clarkson, J.J., Conrad, F., Devey, D.S., Ford, C.S., Hedderson, T.A.J., Hollingsworth, M.L., Husband, B.C., Kelley, L.J., Kesanakurti, P.R., Kim, J. S., Kim, Y.-D., Lahaye, R., Lee, H.-L., Long, D.G., Madriñán, S., Maurin, O., Meusnier, I., Newmaster, S.G., Park, Chong-Wook, Percy, D.M., Petersen, G., Richardson, J.E., Salazar, G.A., Savolainen, V., Seberg, O., Wilkinson, M.J., Yi, D.-K., and Little, D.P., 2009, A DNA barcode for land plants: Proceedings of the National Academy of Science, USA, v. 106, no. 31, p. 12794-12797. https://doi.org/10.1073/pnas.0905845106.

Jurado, V., Sanchez-Moral, S., and Saiz-Jimenez, C., 2008, Entomogenous fungi and the conservation of the cultural heritage: a review: International Biodeterioration and Biodegradation, v. 62, no. 4, p. 325-330. https://doi.org/10.1016/j.ibiod.2008.05.002.

Krantz, G.W., and Walter, D.E, eds., 2009, A Manual of Acarology: Lubbock, Texas Tech University Press, 807 p.

Lahaye, R., van der Bank, M., Bogarin, D., Warner, J., Puplin, F., Gigot, G., Maurin, O., Duthoit, S., Barraclough, T.G., and Savolainen, V., 2008, DNA barcoding the floras of biodiversity hotspots: Proceedings of the National Academy of Science, USA, v. 105, no. 8, p. 2923-2928. https:// doi.org/10.1073/pnas.0709936105.

Lorch, J.M., Lindner, D.L., Gargas, A., Muller, L.K., Minnis, A.M., and Blehert, D.S., 2013, A culture-based survey of fungi in soil from bat hibernacula in the eastern United States and its implications for detection of Geomyces destructans, the causal agent of bat white-nose syndrome: Mycologia, v. 105, no. 2, p. 237-252. https://doi.org/10.3852/12-207.

Martini, J., and Kavalieris, I., 1976, The karst of Transvaal (South Africa): International Journal of Speleology, v. 8, p. 229-251. https://doi. org/10.5038/1827-806x.8.3.1.

Nielsen, U.N, Ayre, E., Wall, D.H., and Bardgett, R.D., 2011, Soil biodiversity and carbon cycling: a review and synthesis of studies examining diversity-function relationships: European Journal of Soil Science, v. 62, no. 1, p. 105-116. https://doi.org/10.1111/j.1365-2389.2010.01314.x.

Nováková, A., 2009, Microscopic fungi isolated from the Domica Cave system (Slovak Karst National Park, Slovakia): a review: International Journal of Speleology, v. 38, no. 1, p. 71-82. https://doi.org/10.5038/1827-806x.38.1.8.

O'Donnell, K., and Cigelnik, E., 1997, Two divergent intragenic rDNA ITS2 types within a monophyletic lineage of the fungus Fusarium are nonorthologous: Molecular and Phylogenetic Evolution, v. 7, no. 1, p. 103-116. https://doi.org/10.1006/mpev.1996.0376.

Patwardhan, A., Ray, S., and Roy, A., 2014, Molecular markers in phylogenetic studies - a review: Journal of Phylogenetics and Evolutionary Biology, v. 2, no. 2, paper 131, 9 p. https://doi.org/10.4172/2329-9002.1000131.

Portillo, M.C., Gonzalez, J.M., and Saiz-Jiminez, C., 2008, Metabolically active microbial communities of yellow and grey colonizations on the walls of Altimera Cave, Spain: Journal of Applied Microbiology, v. 104, no. 3, p. 681-691. https://doi.org/10.1111/j.1365-2672.2007.03594.x.

Schoch, C.L., Seifert, K.A., Huhndorf, S., Robert, V., Spouge, J.L., Levesque, C.L., Chen, W., and Fungal Barcoding Consortium, 2012, Nuclear ribosomal internal transcribed spacer (ITS) region as a universal DNA barcode marker for Fungi: Proceedings of the National Academy of Science, USA, v. 109, no. 16, p. 6241-6246. https://doi.org/10.1073/pnas.1117018109.

Shapiro, J., and Pringle, A., 2010, Anthropogenic influences on the diversity of fungi isolated from caves in Kentucky and Tennessee: The American Midland Naturalist, v. 163, no. 1, p. 76-86. https://doi.org/10.1674/0003-0031-163.1.76.

Song, J., Shi, L., Li, D., Sun, Y., Niu, Y., Chen, Z., Luo, H., Pang, X., Sun, Z., Liu, C., Lv, A., Deng, Y., Larson-Rabin, Z., Wilkinson, M., and Chen, S., 2012, Extensive pyrosequencing reveals frequent intra-genomic variations of internal transcribed spacer regions of nuclear ribosomal DNA: PLoS One, v. 7, p. e43971, 12 p. https://doi.org/10.1371/journal.pone.0043971.

Sugita, T., Kikuchi, K., Makimura, K., Urata, K., Someya, T., Kamei, K., Niimi, M., and Uehara, Y., 2005, Trichosporon species isolated from guano samples obtained from bat-inhabited caves in Japan: Applied and Environmental Microbiology, v. 71, no. 11, p. 7626-7629. https://doi. org/10.1128/AEM.71.11.7626-7629.2005.

Vanderwolf, K.J., Malloch, D., McAlpine, D.F., and Forbes, G.J., 2013, A world review of fungi, yeasts and slime molds in caves: International Journal of Speleology, v. 42, no. 1, p. 77-96. https://doi.org/10.5038/1827-806X.42.1.9.

Visagie, C.M., Hirooka, Y., Tanney, J.B., Whitfield, E., Mwange, K., Meijer, M., Amend, A.S., Seifert, K.A., and Samson, R.A., 2014, Aspergillus, Penicillium and Talaromyces isolated from house dust samples collected around the world: Studies in Mycology, v. 78, p. 63-139. https://doi. org/10.1016/j.simyco.2014.07.002.

White, T.J., Bruns, T.D., Lee, S.B., and Taylor, J.W., 1990, Amplification and direct sequencing of fungal ribosomal RNA genes for phylogenetics, in Innis, M.A., Gelfand, D.H., Sninsky, J.J., and White, T.J., eds., PCR Protocols: a Guide to Methods and Applications. Academic Press, London, p. 315-322.

Woese, C.R., Kandler, O., and Wheelis, M.L., 1990, Towards a natural system of organisms: proposal for the domains Archaea, Bacteria, and Eucarya: Proceedings of the National Academy of Science, USA, v. 87, no. 12, p. 4576-4579. https://doi.org/10.1073/pnas.87.12.4576.

Zhang, Z., Schwartz, S., Wagner, L., and Miller, W., 2000, A greedy algorithm for aligning DNA sequences: Journal of Computational Biology, v. 7, no. 1-2, p. 203-214. https://doi.org/10.1089/10665270050081478. 